\title{
A Tentative Debate on Practical Teaching System for English Majors in Application-oriented Colleges
}

\author{
Jiahuang Chen \\ School of Foreign Languages \\ Sichuan Minzu College \\ Kangding, China 626001
}

\begin{abstract}
The proceeding of practical teaching system for English majors in application-oriented colleges must be strengthened, which is an urgent demand for English majors' teaching reform and their talents cultivation as well. Hence, it is proposed in the paper that practical teaching should be implemented in the colleges in accordance with the goaloriented principle, systematic principle, and regular principle. Moreover, practical teaching system for English majors in application-oriented colleges requires the innovation of pedagogical ideas and methodologies, the amelioration of supervision system for practical teaching quality, and the cultivation of double-professionally-titled teachers.
\end{abstract}

Keywords-application-oriented college; English majors; practical teaching system

\section{INTRODUCTION}

For a very long time, English majors, influenced by traditional pedagogy, had overemphasized their pure disciplinary but neglected the cultivation of student's practical competence, so that they cannot meet the social demand for talents and make their disciplinary and instrumentality into a heated debate. (DAI Wei-dong\& ZHANG Xue-mei, 2007, p.4) For instance, students of English majors were often criticized for their lack of practical experiences and practical competence although they might be inculcated with much antiqued knowledge. In the last decade, accordingly, the call for strengthening English majors' practical training has become more and more urgent. In 2000, the Chinese Education Ministry ratified Teaching Syllabus for English Majors, which advocated that classroom teaching should be integrated with extracurricular practical activities, because these activities could complement what had been taught in the classroom, but they should be conducted under the guidance from the teachers with a clear aim, plan and organization; In 2010, the Chinese Education Ministry issued National Outline for Medium and LongTerm Educational Reform and Development (2010-2020), which highlighted that colleges should support students' academic research, strengthen their practical activities, and promote their entrepreneurial education; in 2015, the Chinese Education Ministry enacted Guidance of Some Local Undergraduate Colleges' Transforming into Applied Colleges, which suggested that some local undergraduate colleges should be transformed into applied colleges; in 2018, the Chinese Education Ministry promulgated National
Standards of Teaching Quality for Undergraduate English Majors, which underlined students' application ability by means of more practical training. In a word, it's really imperative that English majors should be equipped with more practical training, which should be more prioritized in application-oriented colleges.

\section{PRINCIPLES FOR FORMULATING PRACTICAL TEACHING SYSTEM}

Practical teaching system calls for an accurate outlook on practice. Traditional viewpoint towards practice held that practice, mainly involved with survey and internship, was subsidiary to theory; as a result, practical teaching out of the class was usually regarded as the extension and complementation of theoretical teaching in the class. However, the practical teaching in a wider sense, including theoretically practical teaching and socially practical teaching, should penetrate the whole teaching process. Generally speaking, practical teaching can be classified into classroom practical teaching, campus practical teaching, and social practical teaching. (HAN Ke, 2009, p.186-187) Practical teaching in a wider sense should be comprehensive and multicomponent, so to formulate practical teaching system requires an accurate viewpoint of practice and some reasonable principles.

To begin with, practical teaching system should abide by goal-oriented principle. To cultivate qualified talents, practical teaching system for English majors should be centered on the national policies and guidelines, such as Teaching Syllabus for English Majors, Guidance of Some Local Undergraduate Colleges' Transforming into Applied Colleges, and National Standards of Teaching Quality for Undergraduate English Majors, etc. In addition, practical teaching system for English majors in application-oriented colleges should be integrated with local conditions, the local economic and cultural conditions in particular, so that it can better practical teaching for English majors of local undergraduate colleges which will produce more interdisciplinary and applied talents for local region.

In addition, practical teaching system should observe systematic principle. The establishment of practical teaching system should take into consideration the features of English majors as well as objectivity of higher education to model the talents; it should emphasize not only practical teaching 
but also theoretical teaching. Moreover, it should lay emphasis on successive fulfillment of practical training as well as rational deployment of evaluation of practical teaching effects; it should not only meet the demand of general practical teaching but also adjust itself to the requirement of local region. In a word, the establishment of practical is teaching system calls for a scientific and systematic method, coordinating time, place, and manner systematically, so that practical teaching can be effectively conducted during the four-year undergraduate teaching.

Last but not least, practical teaching system should comply with regular principle. The regular principle of practical teaching system can be illustrated in the following three aspects: first, the practical teaching is one important component of daily normal teaching activities, which should not be implemented randomly and disorderly but scientifically and regularly; second, practical teaching for English majors in application- oriented colleges should be pushed step by step, namely, it should be carried out according to students' gradual practical competence over time; finally, practical teaching for English majors in application- oriented colleges should be reasonably evaluated and planned, and when integrated with local economic and cultural activities, it should not disorderly influence the colleges' normal daily teaching activities.

\section{PRACTICAL TEACHING S YSTEM FOR ENGLISH MAJORS IN APPLICATION-ORIENTED COLLEGES}

The further development of economic and social development will farther foreground the instrumentality of English majors, as claimed by DAI Weidong \& ZHANG Xuemei, "till now, it has shown that the essential English educational development substantially reflects the instrumentality of English. (DAI Weidong \& ZHANG Xuemei, 2007, p.7) The instrumentality of English, in essence, requires strengthening practical teaching and improving students' practical competence. Moreover, the Chinese Education Ministry, as mentioned above, encourages some local undergraduate colleges' transformation into applied colleges, so it is urgently imperative for local undergraduate colleges to explore practical teaching system for English majors.

Although practical teaching cannot be regarded as a subsidiary to theoretical teaching, practical teaching system for English major should never be separated from theoretical teaching system. LI Danyan holds that college practical teaching system should at least include four parts: basic practice, comprehensive practice, social practice, and professional practice. (LI Danyan, 2006, p.80) Undoubtedly, LI Danyan's practice is combined with theory. NI Shijun also suggests that practical teaching system should be based on three platforms, namely, practical teaching platform, experimental teaching platform, and internship teaching platform, so that students can improve three abilities: basic operational ability, comprehensive professional ability, and innovative competitive ability. Besides, some other Chinese scholars also put forward some similar teaching practical system, for instance, HAN Hongmei proposes that practical teaching system for English majors should involve curricular practice (e.g. practical courses, free individual practice, and organized collective practice) and extracurricular practice (e.g. discipline competition, innovation and entrepreneurship program, tutor's academic research); (HAN Hongmei, 2014, p.225) for another instance, WANG Jiayi asserts that practical teaching system for English majors is composed of two subsystems, basic curricular practical teaching system and comprehensive extracurricular practical teaching system. The former aims to cultivate students' basic technical competence, such as communicative competence, linguistic exchange competence, literal writing competence, discourse analysis competence, specialized business competence, but the latter strives for improving student's comprehensive competence, such as linguistic performative competence, cultural connoisseurship competence, and literary aesthetic competence. (WANG Jiayi, 2010, p.137)

Based on the ideas above, the author also proposes that practical teaching system for English majors in applicationoriented colleges should include two practical teaching subsystems, namely, on-campus practical teaching system and off-campus practical teaching system. On-campus practical teaching system mainly concerns about basic practical teaching, comprehensive practical teaching, profession-oriented practical teaching, major-featured practical teaching, campus professional competition, etc., while off-campus practical teaching system generally refers to off-campus professional competition, off-campus internship, and local practical training, etc. practical teaching system for English majors in application-oriented colleges can be illustrated as follows in "Fig. 1": 
Practical teaching system for English majors in application-oriented colleges

\begin{tabular}{|c|c|c|c|c|c|c|c|}
\hline \multicolumn{5}{|c|}{ On-campus practical teaching system } & \multicolumn{3}{|c|}{ Off-campus practical teac } \\
\hline$\perp$ & & & $\perp$ & 1 & & $T$ & \\
\hline 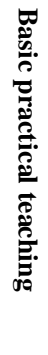 & 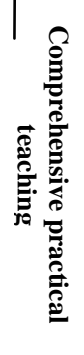 & 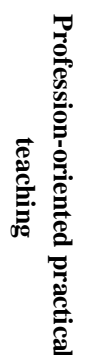 & 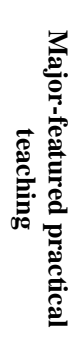 & 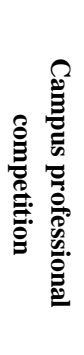 & 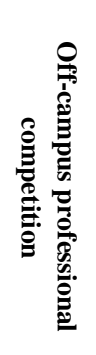 & 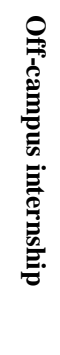 & $\begin{array}{l}5 \\
8 \\
0 \\
0 \\
0 \\
0 \\
0 \\
0 \\
0\end{array}$ \\
\hline
\end{tabular}

Fig. 1. The practical teaching system for English majors in application-oriented colleges.

Basic practical teaching includes the teaching of those basic professional courses stated in Teaching Syllabus for English Majors, such as English Grammar, Basic English, English Listening Comprehension, English Phonetics, English Reading Comprehension, English Writing, Theory and practice of Translation, etc. The basic professional courses are usually opened for freshmen or sophomores. Comprehensive practical teaching involves the teaching of those specialized knowledge courses stated in Teaching Syllabus for English Majors, such as English Linguistics, English Lexicology, English Stylistics, American and British Literature, Western Cultures, Foreign Trade Business, Management Science, Journalism, Pedagogics, etc. Comprehensive practical teaching courses are usually set for junior or senior students. Profession-oriented practical teaching refers to the teaching of students' future career, such as teacher-training, English commercial specialists training, translating or interpreting training. Major-featured practical teaching can be diverse with local conditions and demands, for instance, the college where the author is teaching now is located in Garze Tibetan Autonomous Prefecture which is characterized with tourism and Khampa Tibetan cultures, so English major-featured practical teaching in author's college covers such courses as Khampa Tourism, English Introduction of Tibetan Culture, Basic Tibetan Language, etc. Campus professional competition refers to the professional contest on campus for English majors, such as English speech contest, English lexical contest, English writing contest, English drama contest, English dubbing contest, English song contest, and some academic and entrepreneurial project for students, etc.

Off-campus professional competition refers to provincial, national, or international competition held outside the campus, such as FLTRP (Foreign Language Teaching and Research Press) English speech or writing contest, English World translation contest, provincial or national innovation and entrepreneurship contest, etc. Off-campus internship comprises the summer or winter internship, graduation field work, etc. Local practical training is the highlight of practical teaching for English majors in application-oriented colleges, which requires establishing an intimate relationship between colleges and local regions and building a good cooperation between colleges and local enterprises. For instance, the college the author is working now offers English major students numerous opportunities to accept the local practical training, such as English volunteers or English hosts for "Zhuanshan Festival in Paoma Mountain", "Gongga International Mountain Trail Challenge", " Kangding International Love Song Festival", English guides in Mugecuo Scenic Spot, Hailuogou Scenic Spot, or Paomashan Scenic spot, and English translators for Garze Daily newspaper, etc.

\section{PRIORITIES OF PRACTICAL TEACHING S YSTEM FOR ENGLISH MAJORS}

Practical Teaching System for English Majors in application-oriented colleges cannot be effectively implemented without the joint efforts of local region and college itself. Moreover, three priorities should be given to the implementation of Practical Teaching System for English Majors in application-oriented colleges.

The first priority should be given to the innovation of pedagogical ideology and methodology. Practical Teaching System for English Majors in application-oriented colleges urgently demands updating tutors' teaching ideas and methods. The traditional teaching methods, such as cramming teaching, spoon-feeding teaching, and teachercentered teaching should be abolished and they should be replaced with heuristic teaching, provocative teaching, communicative teaching, and student-centered teaching. The traditional teaching methods cannot intrigue student's interest in and enthusiasm over what they are taught but depress or even kill the impetus for students to probe into what they are going to learn. However, the modern teaching method will fully ignite students' curiosity about what they are about to acquire and effectively improve their practical competence. Hence, the amelioration of tutors' pedagogical ideology and methodology can help students find their deficiency in practical teaching and cultivate their ability to solve problems. 
The second priority should be dedicated to supervision and control system of practical teaching quality and effect. As mentioned above, Practical teaching system for English majors in application-oriented colleges should abide by goaloriented principle, systematic principle, and regular system. The supervision and control system of practical teaching quality and effect can be regarded as the concrete embodiment of those principles as well as the cogent guarantee for those principles. The supervision and control system of practical teaching quality, which aims at improvement of pedagogical ideas, teaching regulations, and teaching mechanism, is composed of four elements, namely, evaluation criteria of practical teaching, feedback of practical teaching, supervision of practical teaching, and management of practical teaching. Among these four elements, the author feels inclined to lay special stress on evaluation criteria of practical teaching. Evaluation criteria of practical teaching should be different from traditional evaluation in that traditional evaluation solely focuses on students' scores of final exams but evaluation criteria of practical teaching is more diversified and dynamic, taking students' daily practical performance into evaluation, such as students' academic research, professional contest result, students' initiative in practice, innovation and entrepreneurship project, and patented invention, etc.

The third priority should be attached to cultivation of double-professionally-titled teaching faculty. Generally speaking, double-professionally-titled teaching faculty in application-oriented colleges should be equipped with three competences, i.e., professional theoretical teaching competence, professional practical competence, and applied academic research competence. (XING Saipeng, 2015, p.46) Double-professionally-titled teaching faculty plays a vital role in practical teaching system for English majors in application-oriented colleges, because they can more efficaciously guide students how to conduct their practice so as to help students improve their practical competence better. The application-oriented colleges should spare on efforts to cultivate double-professionally-titled faculty in the following three ways: first, colleges should take the very advantage of employing bi-expertise faculty; second, colleges should try their best to invite or hire some proficient and experienced technicians from enterprises to be colleges' part-time teaching staff; third, colleges should further on-the-job training for teachers by means of encouraging and supporting teachers' pursuit of higher degree at home or abroad, helping newly-employed faculty plan their career, selecting some teachers to participate in entrepreneurial practical training, etc. (JIA Wensheng, 2015, p.94-95).

\section{CONCLUSION}

English majors in application-oriented colleges, confronted with fierce challenges and severe competitions, should highlight more practical teaching, which reflects the social and temporal demand for English undergraduates. The modern digital information age urges colleges to cultivate students' practical competence; accordingly, it is urgently imperative for application-oriented colleges to explore a feasible and reasonable practical teaching system for English majors. Only by means of updating pedagogical methodology, establishing supervision system for practical teaching, and cultivating double-professionally-titled teachers can practical teaching system for English majors in application-oriented colleges be more effectively implemented.

\section{REFERENCES}

[1] Dai Weidong \& Zhang Xuemei. "On the Undergraduate Programs in China's English Majors”. Foreign Language World, 2007(4)

[2] Han Hongmei. "Construction of Practical Teaching System for English Majors in Application-Oriented Colleges". Education Teaching Forum, 2014(23).

[3] Han Ke. "Construct and Implement a Quality Supervision System for the Practical Teachhing”. Journal of Guangdong Polytechnic Normal University, 2009(1).

[4] Jia Wensheng. "Construction of Double-Professionally-Titled Teaching Faculty Based on the College-Enterprise Community". China Higher Education Research. 2015(1).

[5] Li Danyan. "The Conceived System of Practical Education in Normal University". Heilongjiang Research on Higher Education, 2006(6).

[6] Ni Shijun. "Undergraduate Practical Teaching System: Three Platforms for Students' Three Competences". China University Education, 2008(1).

[7] Wang JIayi. "A Research on the Design of Practical Teaching System for English Majors". Foreign Language and Literature, 2010(6).

[8] Xing Saipeng. "Research on Evaluation Criterion of 'DoubleProfessionally-Titled' Teachers of Application-oriented Undergraduate Institutes". Vocational Technical Education, 2015(4). 